\title{
Genetic potential of cassava biodiversity in Bangka Island, Indonesia
}

\author{
TRI LESTARI", RION APRIYADI \\ Departement of Agrotechnology, Universitas Bangka Belitung. Desa Balunijuk, Kecamatan Merawang, Kabupaten Bangka 33172, Provinsi Kepulauan \\ Bangka Belitung, Indonesia. Tel./fax.+62-717-4260048, `email: trilestari25sm07@gmail.com
}

Manuscript received: 1 May 2017. Revision accepted: 6 September 2017.

\begin{abstract}
Lestari T, Apriyadi R. 2017. Genetic potential of cassava biodiversity in Bangka Island, Indonesia. Cell Biol Dev 1: 41-45. Cassava is potentially a mixture ingredient of flour in the Bangka's food industry. This study aimed to discover the biodiversity of local cassava in Bangka. This research was conducted in the experimental field of the Faculty of Agriculture, University of Bangka Belitung, Indonesia, from July 2015 to July 2016. The experimental design was randomized block design with 10 local cassavas of Bangka that consisted of upang, sekula, bayel, mentega, kuning, batin, pulut, sutera, rakit, and Selangor. Isozyme analysis was performed using starch gel electrophoresis with horizontal models. Analysis for five Bangka local cassava varieties and one National cassava variety used RAPD group OP A and OP B. The results showed that the phenotypic performance was different on the type of plant, the morphology of leaves, stems, and tubers of local cassava of Bangka. Furthermore, isozyme analysis showed a polymorphic banding pattern, while the eight RAPD primers used did not produce polymorphic. Furthermore, this research showed Bangka local cassava morphologically different based on visual observation. The morphological character of the Bangka local cassava leaf was divided into three shapes of lobe: ellipse (upang, sekula, bayel, mentega, batin, pulut, rakit, Selangor), linear (kuning), and lanceolate (sutera). This research data showed that local cassava's genetic diversity in Bangka is relatively high. Therefore, Bangka local cassava has the genetic potential for plant breeding as a plant propagation material.
\end{abstract}

Keywords: Isozyme, morphological, PCR, Manihot esculenta, primer

\section{INTRODUCTION}

Bangka Belitung Province. Indonesia is an archipelago that consists of two big islands, Bangka and Belitung. Bangka Belitung is geographically located between $0^{\circ} 50^{\prime}$ $4^{\circ} 10^{\prime} \mathrm{S}$ and $104^{\circ} 50^{\prime}-109^{\circ} 30^{\prime} \mathrm{E}$. The province of Bangka Belitung Island is divided into land and sea areas, reaching $81,725.14 \mathrm{~km}^{2}$. The land area is approximately $16,424.14$ $\mathrm{km}^{2}$, or 20.10 percent of the total area, and the sea area of approximately $65,301 \mathrm{~km}^{2}$, or $79.90 \%$ of the total area of Bangka Belitung Province.

Cassava is one kind of tuber plant used as food. Cassava ranks five as a world food crop but two for tuber crops after potatoes. The position at number five after rice, wheat, corn, and potatoes. Cassava can grow rapidly. One modification of cassava is mocav, which can be used as a mixture of flour in the food industry. Cassava is a plant with the potency to be developed as the main ingredient for the local food industry in Bangka. Saelim et al. (2008) stated that genetically modified cassava could potentially be developed for food and non-food industries.

Based on BPS data (2015), the productivity of cassava in Indonesia increased from $2011\left(20,298\right.$ tons $\left.\mathrm{ha}^{-1}\right)$ to $2014\left(22,829\right.$ tons $\left.\mathrm{ha}^{-1}\right)$. However, although cassava production in Indonesia continued to increase until 2014, Indonesia still imported cassava from other countries. Therefore, the production and productivity of cassava must be improved according to its genetic potential.

The efforts to develop cassava based on industries' need and use cassava as a food ingredient requires plant breeders to produce new varieties with several advantages, including high yield. Enhancement yield potential can be done if genetic diversity resources are available. However, cassava is a plant that can be propagated vegetatively, and the flowering phase needs a specific location only at elevations above $800 \mathrm{~m}$ asl. That is the reason that causes cassava has low genetic diversity, especially in Indonesia.

Bangka local cassava needs to be identified to see morphological patterns' biology, and genetic diversity. Morphological characteristics of the plant are closely related to growth rate, adaptation character, and the ability to produce good quality tuber. One effort to determine crop biology and genetic diversity can be made using isozyme analysis. The enzyme system's biology and genetic diversity banding pattern will be known through isozyme analysis.

The molecular markers were an effective technique in genetic analysis and were widely applied in the breeding program. Molecular markers include isozyme and DNA markers, such as the RAPD method (Yunus 2007). Priadi et al. (2009) stated that SSR markers could be routinely used in breeding programs to verify the paternity of interspecific crosses of cassava. This study aimed to discover the diversity of Bangka local cassava as a genetic resource for plant propagation.

\section{MATERIALS AND METHODS}

Exploration was conducted in three Bangka Island, Indonesia, including West Bangka District, Bangka District, and South Bangka District. First, the samples were planted, and then morphological character identification of 
cassava was observed. The research was conducted in the experiment field of the Faculty of Agriculture, University of Bangka Belitung, and Biology Laboratory of PPSH IPB Bogor, Indonesia, from July 2015 to July 2016.

Planting was done using stem cuttings of cassava. Cassava stems were planted with $100 \mathrm{~cm} \times 100 \mathrm{~cm}$ spacing in a $2 \mathrm{~m} \times 5 \mathrm{~m}$ plot with a $1 \mathrm{~m}$ distance between the plots. The cuttings position was perpendicular or at least $60^{\circ}$ from the ground. The cutting depth was $10-15 \mathrm{~cm}$. Fertilizers were given to the hole before planting in the field. Fertilization was done by providing NPK fertilizers composition: $\mathrm{N}$ : $100 \mathrm{~kg} \mathrm{ha}^{-1}, \mathrm{P}: 30 \mathrm{~kg} \mathrm{ha}^{-1}, \mathrm{~K}: 50 \mathrm{~kg} \mathrm{ha}^{-1}$. The dosage of basic fertilizer (1/3 dose of urea, KCL, and the entire dose of TSP) was given at the planting timer.

Observation of the qualitative character was carried out by scoring 16 characters based on the characterization by Fukuda et al. (2010). The isozyme analysis method used starch gel electrophoresis horizontal models with peroxidase (PER). The genetic analysis applied to five Bangka local cassava varieties derived from the isozyme analysis result, which classified two subgroups based on similarity coefficient. Therefore, four Bangka local cassava varieties were chosen as RAPD samples based on the isozyme analysis result. In addition, new Bangka local varieties, namely 3 Bulan and one national variety (Malang 6 ), were also used as comparison genotypes. Therefore, there were six genetic analysis samples using RAPD group OP A and OP B (Xue et al. 2010).

Visualization isozyme band form translated into binary data, and the result analysis is based on the presence or absence of the band. Score 1 for the presence band and 0 for the absence band. Then the binary data was converted into a coefficient based on the similarity matrix SM (Simple Matching). Finally, the resemblance value for clustering analysis was calculated using the UPGMA method (Unweighted Pair-Group Method with arithmetic averaging) from NTSYSpc (Numerical Taxonomy System) program version 2.0 .

\section{RESULTS AND DISCUSSION}

The research results showed that 10 local cassava could be found across three districts (West Bangka, Bangka, and South Bangka). Plant character variations may be influenced by genes as an internal factor and supported by environmental factors as a stimulant to express the characters.

Table 1. Plant type of Bangka local cassava

\begin{tabular}{llll}
\hline $\begin{array}{l}\text { Clone of } \\
\text { cassava }\end{array}$ & $\begin{array}{l}\text { Type of } \\
\text { branching }\end{array}$ & $\begin{array}{l}\text { Plant } \\
\text { high }(\mathbf{c m})\end{array}$ & $\begin{array}{l}\text { Harvesting } \\
\text { (days) }\end{array}$ \\
\hline Upang & Tetrachotomy & 250 & $210-230$ \\
Sekula & Trichotomy & 300 & $180-215$ \\
Bayel & Dichotomy & 250 & $210-235$ \\
Mentega & Tetrachotomy & 250 & $150-185$ \\
Kuning & Tetrachotomy & 250 & $120-151$ \\
Batin & Trichotomy & 300 & $120-151$ \\
Pulut & Trichotomy & 300 & $120-155$ \\
Sutera & Tetrachotomy & 350 & $210-255$ \\
Rakit & Dichotomy & $150-250$ & $120-180$ \\
Selangor & Trichotomy & 300 & $160-210$ \\
\hline
\end{tabular}

The branching type of cassava is divided into 3 types, consist with dichotomy (bayel, rakit), trichotomy (sekula, batin, pulut, Selangor), and tetrachotomy (upang, mentega, kuning, sutera). Plant height averages of 10 local cassava clones Bangka are $150-350 \mathrm{~cm}$. The average harvest age of 10 cassava is $120-230$ days (Table 1 ).

The morphological character of the Bangka local cassava leaf was divided into 3 shapes of the lobe, i.e., ellipse (upang, sekula, bayel, mentega, batin, pulut, rakit, Selangor), linear (kuning) and lanceolate (sutera) (Figure 3; Table 2). Furthermore, the color of young leaves of Bangka local cassava is divided into 3 colors, i.e., light green (upang, sekula, sutera, rakit), brownish-green (bayel, mentega, kuning, batin, Selangor) and greenish brown (pulut). The color of old leaves of Bangka local cassava is divided into 2 color, i.e., green (upang, sekula, bayel, mentega, kuning, pulut, sutera, rakit, Selangor) and old green (batin) (Table 2).

Morphology of Bangka local cassava young stems was divided into four colors, i.e., green (upang, mentega, kuning, sutera), green striped purple (sekula, Selangor), green striped red (bayel, batin, pulut) and light green striped (rakit) (Table 3). The old stem color of Bangka local cassava was dominated by greenish gray (upang, sekula, batin, pulut, and sutera), followed by grey (bayel), brownish green (mentega), light brown (kuning), reddish brown (rakit), and grey (Selangor). Halsey et al. (2008) reported that the risk of gene flow under natural conditions might be limited to a specific subset of wild relatives or conditions due to the natural constraints discussed above.

Morphology of Bangka local cassava tubers divided into two tuber shapes, i.e., conical (upang, sekula, bayel, mentega, kuning, batin, pulut, rakit) and cylindrical (sutera, Selangor). The outside skin color of the Bangka local cassava tubers is divided into five colors, i.e., brown (upang, mentega, kuning, batin, sutera, rakit), reddish brown (sekula), brownish gray (bayel), yellowish gray (pulut) and grayish white (Selangor). Local color of Bangka local cassava tubers are divided into 3 colors, i.e., white (upang, sekula, bayel, batin, pulut, sutera, rakit, selangor), young yellow (mentega), and yellow (kuning) (Table 4). Tubers can potentially be developed as the main ingredient for the local food industry in Bangka. Saelim et al. (2008) stated that genetically modified cassava is an environmentally friendly plant that derives products from food and non-food industries.

Table 2. Leaf morphology of Bangka local cassava

\begin{tabular}{lllc}
\hline Clone & $\begin{array}{l}\text { Shape of } \\
\text { lobe }\end{array}$ & $\begin{array}{l}\text { Young leaf } \\
\text { color }\end{array}$ & Old leaf color \\
\hline Upang & Ellipse & Light green & Green \\
Sekula & Ellipse & Light green & Green \\
Bayel & Ellipse & Brownish green & Green \\
Mentega & Ellipse & Brownish green & Green \\
Kuning & Linear & Brownish green & Green \\
Batin & Ellipse & Brownish green & Dark green \\
Pulut & Ellipse & Greenish brown & Green \\
Sutera & Lanceolate & Light green & Green \\
Rakit & Ellipse & Light green & Green \\
Selangor & Ellipse & Brownish green & Green \\
\hline
\end{tabular}


Table 3. Stem color of Bangka local cassava

\begin{tabular}{lll}
\hline Clone & Young stem & Old stem \\
\hline Upang & Green & Greenish-gray \\
Sekula & Green striped purple & Greenish-gray \\
Bayel & Green striped red & Grey \\
Mentega & Green & Brownish green \\
Kuning & Green & Light brown \\
Batin & Green striped red & Greenish-gray \\
Pulut & Green striped red & Greenish-gray \\
Sutera & Green & Greenish-gray \\
Rakit & Light green striped & Reddish brown \\
Selangor & Green striped purple & Grey \\
\hline
\end{tabular}

Table 4. Tuber morphology of Bangka local cassava

\begin{tabular}{llll}
\hline Clone & Tuber shape & $\begin{array}{c}\text { Color of outside } \\
\text { skin }\end{array}$ & $\begin{array}{c}\text { Color of } \\
\text { flesh }\end{array}$ \\
\hline Upang & Conical & Brown & White \\
Sekula & Conical & Reddish brown & White \\
Bayel & Conical & Brownish gray & White \\
Mentega & Conical & Brown & Light yellow \\
Kuning & Conical & Brown & Yellow \\
Batin & Conical & Brown & White \\
Pulut & Conical & Yellowish gray & White \\
Sutera & Cylindrical & Brown & White \\
Rakit & Conical & Brown & White \\
Selangor & Cylindrical & Grayish white & White \\
\hline
\end{tabular}

Morphology characters of Bangka local cassava have many differences based on the observed variables such as the shape of the leaf, leaf color, stem color, tuber shape, and color of the tuber. Differences in the characters that occur may cause by a genetic trait that controls the characters' expression and is influenced by the environmental condition. Hurtado et al. (2008) stated that differences in plant character might cause by differences composition of genes possessed by each plant. Environmental condition as a stimulant factor also takes responsibility for the plant's character. Dasumiati et al. (2017) reported the differences in sex types in the flower of Jatropha curcas due to their responsiveness to the environment in two different locations.

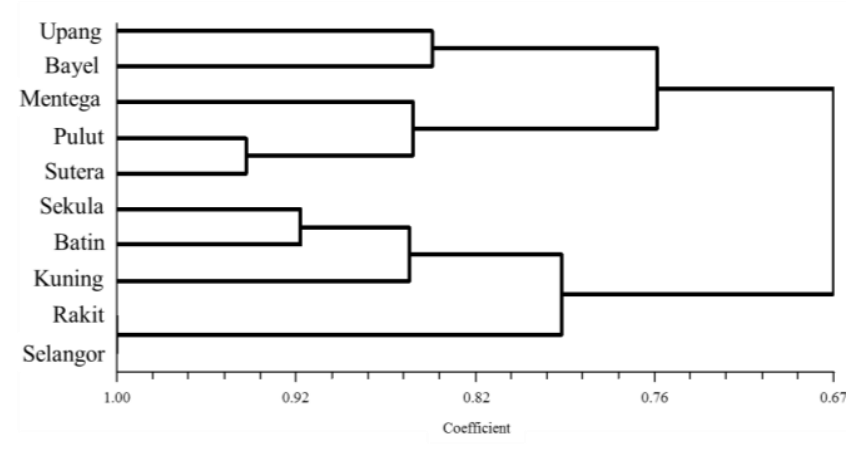

Figure 1. Dendrogram of 10 Bangka cassava using isozyme analysis
Morphological observation using the isoenzyme of 10 Bangka local cassava was given by score based on their band (1) and the absence of band (0), and the score of the group analysis (cluster analysis) was made by using a dendrogram. The similarity coefficient of 0.742 . Based on the level of similarity, 10 Bangka local cassava clones can be grouped into two groups. The first group consisted of upang, bayel, mentega, pulut, and sutera. The second group consisted of sekula, batin, kuning, rakit, and Selangor (Figure 1).

Results of the study showed that isozyme analysis on 10 Bangka local cassava samples had variations in polymorphic isozyme banding patterns (Figure 2). Polymorphic isozyme basically could be separated although it was contained in the same organism. Different system enzymes that catalyze a reaction in the cell can be seen through the banding pattern differences by starch gel electrophoresis method after coloring. Hamzah et al. (2009) reported that the mating system of bakau bandul (Rhizophora mucronata Lamk) using peroxidase isozyme analysis produces a polymorphic banding pattern.

Isozyme can be used as a genetic trait to study the genetic diversity of an individual in a population, classification of plant species, and identify cultivars hybrid. Utilization of isozyme banding pattern for the benefit of plant biology, including plants' physiology properties, is more reliable because it is governed by a single gene, codominant inheritance, and normal segregation according to the Mendelian ratio. The isozyme technique has proven to be a fast and economical method. Isozyme analysis can also be used in almost all plant tissues. The final choice depends on the availability of plant material and biochemical activity in the plant tissue with a high content of secondary metabolites such as leaves. Isozyme analysis using peroxidase enzyme is previously conducted in analyzing the diversity of cassava to produce two banding pattern peroxidase enzymes that migrate to the positive and negative poles.

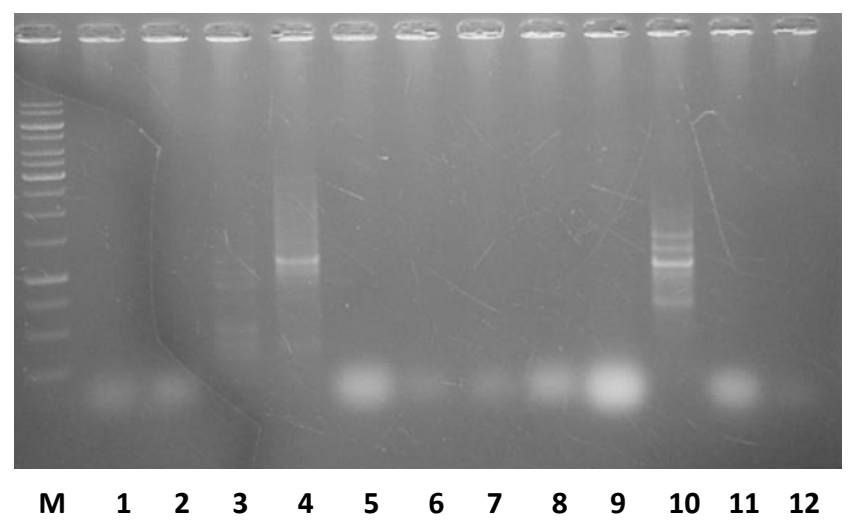

Figure 2. RAPD analysis cassava with primer OP B04 dan OP B06 (118816). Note: 1. Malang 6 variety, 2. Batin, 3. 3 Bulan, 4. Sutera, 5. Mentega, 6. Rakit, 7. Malang 6 variety, 8. Batin, 9. 3 Bulan, 10. Sutera, 11. Mentega, 12. Rakit 
The results showed the different performance of qualitative data of five Bangka local cassava varieties and one national variety (Malang 6) on observing morphological characters at five months old plants. Bangka local cassava is morphologically different based on visual observation, but the molecular diversity was unknown. Morphological characters showed the differences between the Bangka local cassava varieties and the comparison. The results showed eight primers used did not produce polymorphic (Figure 2). Hurtado et al. (2013) reported that results SSR markers, while low throughput compared to DArTs, are relatively better at detecting genetic differentiation in cassava germplasm collections. Mezette et al. (2013) reported high genetic diversity among cassava genotypes.

The differences between leaf characters in Figure 3 explain that 8 accessions had similar characters except for kuning and sutera. Kuning accession has a linear lobe shape, while sutera has a Lanceolate lobe shape. On average, most of the leaves had at least seven lobes in 1 leaf except kuning and Selangor, which had eight lobes in one leaf. The environmental condition may affect this character because several leaves in upang, sekula, bayel, mentega, batin, pulut, rakit, and Selangor also have eight lobes in one leaf.

Some characters can be used as a differentiator between local Banka cassava clones. The characteristics were the type of plants and the morphology of leaves, stems, and tubers. Genetic variability in local Bangka cassava clones was based on morphological characters and isoenzyme analysis. The character pattern among the cassava genotypes can be exploited to improve and develop new cassava genotypes (Oduwave et al., 2013; Vieira et al., 2013)

\section{ACKNOWLEDGEMENTS}

The work was supported by a grant for applied research from the Ministry of Research Technology and Higher Education, Republic of Indonesia, 2016.

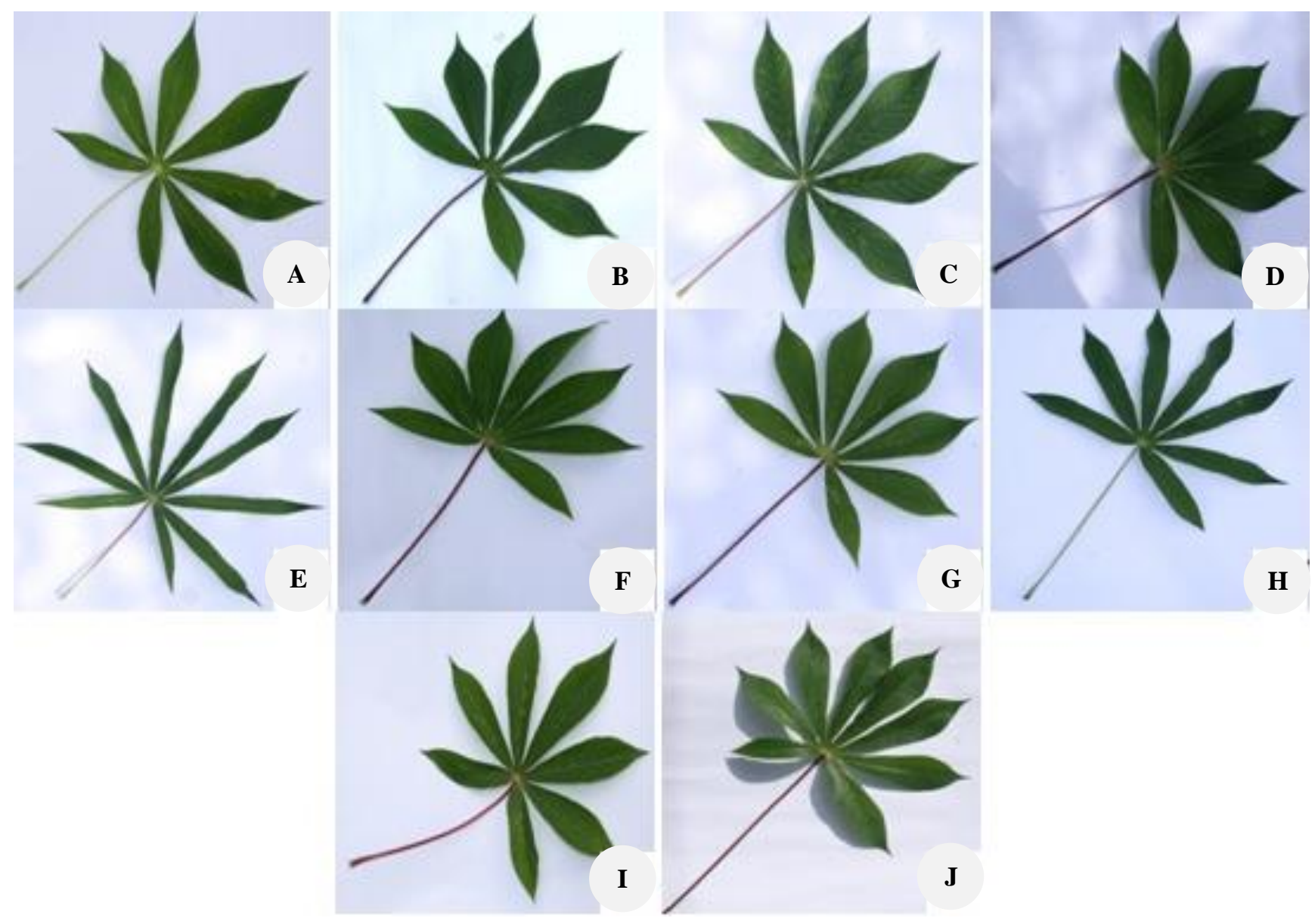

Figure 3. Leaf shape and leaf color of Bangka local cassava. Note: A. Upang, B. Sekula, C. Bayel, D. Mentega, E. Kuning, F. Batin, G. Pulut, H. Sutera, I. Rakit, J. Selangor 


\section{REFERENCES}

BPS [Statistics Bureau of Indonesia]. 2015. Data on harvested area productivity, and production of Indonesian cassava plant. Statistics Bureau of Indonesia, Jakarta. [April 6, 2016].

Dasumiati, Miftahudin, Triadiati, Hartana A. 2017. Sex types in flowering of Jatropha curcas. Biodiversitas 18 (1): 442-446. DOI: 10.13057/biodiv/d180158.

Fukuda WMG, Guevara CL, Kawuki R, Ferguson ME. 2010. Selected morphological and agronomic descriptors for characterization of cassava. International Institute of Tropical Agriculture (IITA), Ibadan, Nigeria.

Hamzah, Siregar UJ, Siregar CA. 2009. Mating system of bakau bandul (Rhizophora mucronata Lamk) based on isozymes analysis. Jurnal Penelitian Hutan dan Konservasi Alam 6 (2): 115-123. DOI: https://doi.org/10.20886/jphk.20009.62115-123

Halsey, Mark E, Olsen, Kenneth M, Taylor, Nigel J, Chavarriaga A, Paul 2008. Reproductive biology of cassava (Manihot esculenta Crantz) and isolation of experimental field trial. Crop Sci 48 (1): 49-58. DOI: 10.2135/Cropsci 2007.05.0279.

Hurtado P, Olsen KM, Buitrago C, Ospina C, Maria J, Dugue M, Viconte CD, Wongtiem D, Wenzel P, kilian A, Adeleke M, Frequene M. 2008. Comparison of simple sequence repeat (SSR) and diversity array technology (DArT) markers for assessing genetic diversity in cassava (Manihot esculenta Crantz). Plant Genetic Resources: Characterization and Utilization 6 (3): 208-214. DOI $10.1017 /$ SI 479262108994181 .
Mezette TF, Blumer CG, Veasey EA. 2013. Morphological and molecular diversity among cassava genotypes. Pesq Agropec Bras 48 (5): 510518. DOI: 10.1590/S0100-204X2013000500007

Oduwaye OA, Ojo DK, Mkumbira J, Alake CO, Adenuga O, Mapayi EF. 2013. Genetic assessment of 23 cassava, Manihot esculenta Crantz. Genotypes at two agro-climatic zones in Nigeria. Plant Breed Seed Sci 6 (1): 103-114. DOI: 10.2478/V10129-011-0073-3.

Priadi D, Permana DR, Dona SE, Hartati S, Sudarmonowati E. 2009. Selection of Indonesia cassava (Manihot esculenta Crantz) genotypes as source of $\mathrm{B}$ carotene. Biodiversitas 10 (1): 6-11. DOI: 10.13057/biodiv/d100102

Saelim L, Phansiri S, Suksangpanomrung M, Netrphan S, Narangajavana J. 2008. Evaluation of a morphological marker selection and excision system to generate marker-free transgenic cassava plants. Plant Cell Rep 28:445-455. DOI: 10.1007/s00299-008-0658-y

Vieira LD, Ficho LFD, Souza FUD, Alves AAC, Oliveira EJD. 2013. Development of interspecific hybrids of cassava and paternity analysis with molecular markers. J Agric Sci 151: 849-861. DOI: $10.1017 / \mathrm{S} 0021859612000871$.

Xue D, Feng S, Zhao H, Jiang H, Shen B, Shi N, Wang H. 2010. The linkage maps of Dendrobium species based on RAPD and SRAP markers. J Genet Genom 37 (3): 197-204. DOI: 10.106/51673-8527 (09)60038-2

Yunus A. 2007. Identification of genetic diversity jarak pagar (Jatropha curcas L.) in Central Java based on isoenzyme marker. Biodiversitas 8 (3): 249-252. DOI: 10.13057/biodiv/d180158 